2. A criação de contribuições corresponde a uma tendência generalizada, não apenas decor rente de uma maior facilidade da administração públicá, quanto à obtenção de recursos, mas ção publica, quanto à obtenção de recursos, mas
tambem por atender melhor as exigências da justiça fiscal, eis que seus contribuintes encontram-se sempre relacionados com o respectivo fato gerador, beneficiando-se direta ou indiretamente com fatos que o compóem.

3. É dominante hoje a opinião que as contribuições parafiscais formam um quarto gênero de tributos, não sendo impostos, nem taxas nem contribuiçōes de melhoria24,25.

4. As normas juridicas constitucionais e complementares não definem as contribuições especiais ou parafiscais.

5. As contribuiçōes parafiscais são, ainda pouco usadas com finalidades compensatórias para direcionar atividades econômicas, área onde poderão tornar-se expressivas.

\section{NOTAS DE REFERÊNCIA}

1 Tipke Die Steuerrechtsordnung, Verlag Dr. Otto Schmidt, Köln, 199 v. III, p. 1070-1074.

2 G. Gest/G. Tixier, Manuel de Droit Fiscal. Paris 1986 p. 58-60 "apud" Tipke.

Maurice Duverger. "Finances Publiques". Presse Universitaires de France, 1963, pp. 92 a 93 "apud", Gilberto de Ulhoa Canto "Contribuições Sociais Cadernos de Pesquisas Tributárias", v. 17, Editora Resenha Tributária, S.P., 1992, p. 43-44.

4 Robert Schumann ou Schuman, então Ministro das Finanças, e, posteriormente, um dos mais impor tantes artifices da Comunidade Européia.

A palavra "Parafiscalidade" e a utilizaçāo da expressão "contribuiçáo fiscal" deve-se a Emanuelle Morselli, "Paraflscallidace Seu Controle" e fol por este Brasileiro de Direito Financeiro, Rio de Janeiro. 1.ed., p. 24, 1954 .

"Parafiscalité, Taxe e Cotisations perçues sous

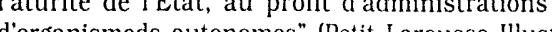
dorganismeds

7 Emanuelle Morselli. "Parafiscalidade e Seu Controle", conferências divulgadas pelo Instituto Brasileiro de Direito Financeiro, Rio de Janeiro, la edicão 1954, p. 282

8 Bernardo Ribeiro de Moraes. Compenndio de Direito

Tributário, 3.ed., Forense, p. 623.

Aspectos da Parafiscalidade. Livraria Progresso Editora, Salvador, 1.ed., 1955.
10 Op. cit., p. 57.

12 Uma Introduçäa à Ciência das Finanças. Editora Forense, Rio de Janeiro, p. 282, 1978.

14 Teoria Geral do Direito Tributário. Saraiva, São Paulo, p. 349, 1963.

15 Trabalhos, p. 23.

16 Trabalhos, p. 271

"Art. 95. Sazo sejam especificamente impostos ou taxas.

grafo Unico. A competência para instituição de contribuiçōes pertence cumulativamente à Art $96: 0$ produto da arrioc

Art buçoes nao pode ser at dabuido, no todo ou em parte, sob pena de legalidade da respectiva cobrança. sido especificamente instituidas. Art. 97: Aplicam-se supletivamente às contribuiçōes as disposiçōes de caráter geral relativas às taxas, contidas neste Código ou na legislação tributária."

18 Trabalhos, n. 36, p. 199:

"O art. 21 do Projeto levantou na Comissão o problema da conceituação das contribuições como uma terceira figura tributária genérica, paralelamente aos impostos e as taxas. Essa orientação, defendida em doutrina pelo autor do Anteprojeto (Revista de Direito Administrativo 26/363) e consignada em seu art. 28, foi atacada pela sugestão 94 , que afirmou năo existirem, alêm da contribuiçăo especificamente "de melhoria", qualificativo sempre usado pela Constituição, outros tributos que não se enquadrem nos conceitos de imposto ou de taxa. A Comissão adotou esse ponto de vista, em que consonanncia com a sua orientação no tocante aos objetivos soclals autor do Anteprojeto no trabalharico de contribuicão estaria na possibilidale genetituir regime juridico especial para as exacões caräter parafiscal: mas exatamente cuanto a essas a Comissão deliberou, em principio, adotar uma atitude de neutralidade juridica (supra: 7)".

19 Rubens Gomes de Sousa. Parecer A Contribuição da Previdencia Social e os Municipios, p. 55

20 . Op. cit., pp. 54, 55.

21 Bernardo Ribeiro de Moraes, op. cit., p. 645.

22 Aliomar Baleeiro. Limitacöes Constitucionais ao Po der de Tributo. Forense, Rio de Janeiro, 5.ed., p. 280, 1977.

24 Gilberto de Ulhoa Canto. Contribuições Sociais. Caderno de Pesquisas Tributárias, v. 17, p. 40.

25 Rubens Gomes de Sousa. Trabalhos, p. 288.

\title{
Successor Corporation Liability for Claims Arising Out of Defective Products*
}

GILBERTO DEON CORRÊA JUNIOR

Mestre em Direito pela UFRGS.

Mestre em Direito Comparado pela New York University.

Procurador da Fazenda Nacional. Advogado em Porto Alegre.

\section{INTRODUCTION}

Rolim Manufacturing Corporation produces hydraulic shearing machines. One of those shearing machines was sold to Greenberger Brothers Company, Inc. While operating the machine, John McGregor, an employee, was struck by a scrap of metal thrown from it. The piece of metal penetrated one of his eyes and he was blinded. It is incontrovertible that the accident happened because the hydraulic shearing machine was defective. Mr. McGregor can therefore seek recovery for personal injury against Rolim.

Let us assume, for instance, that before the injury Rolim merged with Klinger Shearing Corporation. As a result of the merger. McGregor would be able to sue Klinger because it assumed Rolim's liabilities.

Assume the same facts, but instead of having a merger of the corporations, Klinger just bought Rolim's assets, including all the inventory, trade name, secrets and equipment. Rolim was dissolved five years before the accident and since the transaction Klinger has been manufacturing the same shearing machines, unde the same trade name. Does McGregor have cause of action for personal injuries against Klinger? As we are going to see, the answer to this question can vary depending, on which state's law the court applies.

The general rule in most states is that the corporation which acquires the assets of another corporation does not succeed to the liabilities of the former' unless:
1) there is an express or implied agreement of assumption of the liabilities:

2) the transaction amounts to a consolidation or merger of the purchaser and the seller;

3) the purchaser is a mere continuation of the selling corporation; or

4) the transaction was fraudulent. ${ }^{2}$

Some courts add a fifth exception, which is the absence of adequate consideration for the sale or transfer of assets ${ }^{3}$ or the lack of the elements of a purchaser in good faith. ${ }^{4}$

Assuming that the transaction was not fraudulent, Klinger paid adequate consideration and there was no express or implied assumption of liabilities, does McGregor have a cause of action against Klinger?

Exception two, known as de facto merger or consolidation exception, was created to protect the creditors and the minority shareholders in those cases where the companies enter into an agreement that achieves the same results as a merger or consolidation but does not follow the legal steps required in the case no a merger or consolidation. Traditionally, the de facto merger exception requires that the assets be acquired for shares or other securities of the acquiring corporation which are distributed to the company seller shareholders.

The mere continuation exception, on the other hand, causes liability to depend on whether the plaintiff can establish that one or more persons were officers, director, or shareholders of both companies. $^{6}$ 
In our example the assets were bought for cash. Does it mean that Mr. McGregor will no be able to seek recovery against Klinger?

As we said before, the answer will vary, depending on the state law applied. Just to give an idea about the extension of that observation. let us look at some cases involving the same companies that were decided by different courts. In 1956. Johnson Machine and Press Company of Bontrager Construction Compan diana corporation. In 1962, Amsted Industries, Inc. acquired Bontrager's assets. Amsted wa later sued for personal injuries arising out of defective products manufactured by the predecessor corporations. The first two cases wer decided in 1979 and Amsted was held liable as a successor corporation in one of them ${ }^{7}$ and not liable in the other. ${ }^{8}$ Two years later the Supreme Court of New Jersey held Amsted liable for the damages caused to the plaintiff in 1975 by defective punch press manufactured by John son in 1948 or $1949 . .^{9}$ In 1982, m msted was held not liable in a case involving a punch press manufactured in 1960.10 Three years later the mupreme Court of Wisconsin held Amsted Supreme Court of Wisconsi liable as a successor corporation in a case whe re the press had been manufactured by Bontrager in 1957.1

Although the analysis of the circumstance involved in a given case can vary from one cour to another, generally what made the courts reach different results in the above-mentioned cases was the application of different states' laws In other words, the company's liability as a successor corporation is something that in many cases will depend on which state's law that will be applied to the specific case. This creates uncertainty, a result that is clearly undesirable. The problem emerging from that diversity of law, which is a result of the United States federa legal system, is even more serious when we consider the characteristics of today's economy: the products manufactured in one place being distributed all over the country and even all aroun the world. Moreover, the product can be resold and the manufacturer may not know where it is. How could a company that purchases the assets of another corporation possibly know that it will be held liable for injuries caused by defective products made by its predecessor?

The different approaches used by the courts is a result of the way they see the tension between the justification for the traditional corporate rule of successor liability, on one hand, and the policies behind strict liability, on the other Basically, the courts are split in two groups. majority ap majority applies the traditional corporate rule of successor liability even in those cases involving personal injuries caused by a defective product. On the other hand, some courts criticize the traditional approach as being inconsisten with the principles of strict liability in tort and unresponsive to the legitimate interests of the products liability plaintiff. Consequently, these courts started to expand successor liability. According to the reasoning used by the court to reach that result, the courts can be subdivided in two subgroups: first, those courts that expand the de facto merger and mere continuation exceptions in certain situations; second, the that use the "product line" approach.

The analysis of these groups and subgroups is the object of this essay. We are not going to deal here with the duty to warn that some court have decided can create successor liability. A duty to warn can result not from the purchase of the assets in itself but from some relationship established between the successor and the consumer a ceeds to the original manufacturer's service contracts, providing parts and services to the plaintiff or his employer. ${ }^{13}$ When dealing with this issue, the courts usually consider a number of factors, including "succession to service con政 contract, service of that machine by the successor, and the successor's knowledge of the defect and of the machine owner's location". ${ }^{14}$ Moreover, not only does a duty to warn not arise just from the purchase of the assets without a special relationship but it would also be necessary to write a separate paper to cover this issue. ${ }^{15}$
THE EXPANSION OF THE TRADITIONAL

EXCEPTIONS TO THE RULE OF NO

\section{SUCCESSOR LIABILITY}

\section{The Product Line Approach}

The product line exception was first developed by the California Supreme Court in Ray $v$. Alad Corp. ${ }^{16}$

In this case, plaintiff sought recovery arising out of his fall from a defective ladder manufac tured by Alad Corporation (Alad I). Prior to that event, Alad I had sold its stock in trade, fixtures, equipment, inventory, trade name, goodwil and its interest in the real property used for it manufacturing activities to Lighting Maintenance Corporation (Lighting). As part of the transaction, Alad I had agreed to dissolve its corporate existence as soon as possible (Alad I had been already dissolved when plaintiff brought the action) and to cooperate with Lighting in the organization of a new corporation under th same name of Alad Corporation (Alad II). There was no provision in the agreement about the liability for defects in products manufactured or sold by Alad I.

The records in the case showed that the assets acquired by Lighting were used to continue the manufacturing operations, which were in terrupted just for about a week for inventory. The same extrusion plans were used for producing the aluminum components of the ladders. Moreover, the factory personnel remained the same and identical. The general manager designated by Lighting was without experience in this area, and, as a result, the former general manager of Alad I remained as a paid consultant for about six months after the takeover. The Ala name was used in all ladders produced by Alad II, which used Alad I's list of customers and continued to employ the same salesman and representatives. ${ }^{17}$

According to the court, none of the four stated grounds for successor liability under the traditional corporate law were present in the case There was no agreement about the liability arising out of defects in products previously manufactured or sold by Alad I. There was no indication of fraudulent intent. Moreover, there was no identity of ownership. Thus, the transaction could not be considered a de facto merger or consolidation, neither could Alad II be considered a mere continuation of Alad I. Finally, there was not any allegation of inadequate cons tion. Thus, the de facto merger or the mere connuation exceptions could not be applied. ${ }^{18}$

The court noted that the purpose of the rule of strict tort liability, applied in those cases of injuries arising out of defective products, is to protect the victims of manufacturing defects and to promote the spread, throughout society, of the cost of compensating them. ${ }^{19}$ The reason for that is that the "cost of an injury and the loss of time or health may be an overwhelming misfortune to the person injured, and a needless one, for the risk of injury can be insured by the manufacturer and distributed among the public as a cost of doing business." 20 The application of the rules of successor liability to the purchaser of an ongoing business should depend on whether the form and circumstances of the transaction would thwart the policy to be promoted by the strict tort liability rule.

Applying this idea to the case, the Ray court observed the agreement had transferred to Alad II the resources that had previously been available to Alad I for meeting its responsibilities to injured consumers. Alad II had continued the business with the same facilities and sources of information that were available to Alad I and, in this way, had the same capacity as the latter to estimate the risks of claims for injuries resulting from previously manufactured ladders and, thus, obtain insurance coverage or plan self-insurance. Moreover, the cost of that insurance could have been passed on to purchasers of new Alad products.

Furthermore, the consumers' remedies against Alad I were no longer available. If Alad II were not liable, the transaction would have granted Alad II the benefits of Alad l's established reputation as a going concern manufacturing a specific product line without the burden of potential liability for injuries from previously manufactured products, a substantial benefit which Alad II's predecessor could not have enjoyed.

Summarizing, the court held that the reason for imposing strict liability upon Alad II rested upon: 
1) the virtual destruction of the plaintiffs remedies against the original manufacturer as a result of the business acquisition;

2) the successor's ability to assume the riskspreading role of the original manufacturer; and

3) the fairness of requiring the successor to shoulder a responsibility for defective products that was a burden obligatorily connected to the original manufacturer's goodwill being enjoyed by the successor in the continued operation of the business.2 Ray was adopted by the Supreme Court of New Jersey in Ramirez $v$. Amsted Industries, Inc. ${ }^{22}$ In 1975, the plaintiff was injured while operating a power press manufactured by Johnson Machine and Press Company, that had transferred all its assets and liabilities to Bontrager. Although transacting no business as a manufacturing entity, Johnson had continued to exist after the transaction as a Bontrager wholly-owned subsidiary. In 1962, Amsted Industries. Inc. bought all the assets of Bontrager, including the assets of Johnson, as a form to use the Johnson trade name. Bontrager and Johnson were dissolved after the buy-and-sell agreement. Amsted continued to manufactur the same kind of press through a wholly-owne subsidiary, South Bend Lathe, Inc. This subsidiary was later transformed into an unincorporated division of Amsted. In 1975. Amsted sold the Johnson press line to LWE, Inc. which further changed its name to South Bend Lathe, Inc. (South Bend II). Amsted agreed to indemnify LWE, Inc. for claims arising out of defective Johnson presses. ${ }^{23}$

The court first noted that strict interpretation of the traditional corporate rule of successor liability places unwarranted emphasis on the form rather than the practical result of a specific corporate transaction. ${ }^{24}$ After analyzing the mere continuation exception, which, according to the court, merely broadens the traditional exceptions to the rule of no successor liability, the court decided to adopt Ray, that focuses on the continuation of essentially the same line of products; the focus should be on the continuation of the manufacturing operation and not on the commonality of ownership and management

between the seller and the purchaser corporati-

In the same year, the Superior Court of Pennsylvania adopted Ray in Dawejko v. Jorgensen Steel Co. ${ }^{25}$ a case where the plaintiff had been injured by sheets of steel accidentally dropped from a lifting machine. The court noted that the product line exception was an attempt to implement the social policies underlying strict products liabilities; thus, the other exceptions to corp thus, the other exceplons to in the case of the purchase of assets should be used whe of purchase of assets should be used when dealing with cases not so much affected by those policies. ${ }^{26}$ This suggests that the court was unwilling to apply the same expansive approach to traditional doctrines in cases not involving claims related to product liability.

Moreover, the court pointed out that it would be preferable to phrase the new exception in general terms, allowing the courts to apply the product line approach in a case by case analysis, considering, for example, whether the successor advertised itself as an ongoing enterprise, maintained the same product, name, personnel, property and clients, and whether the predecessor was dissolved. Furthermore, it would be important to consider if the three-part test announced in Ray were met, which suggests that the exception could be applied even in those cases where not all the three requirements are present. ${ }^{27}$ However, that impression was not confirmed by a later case, Hill v. Trailmobile, Inc. which said that the product line exception should be applied only where all the three circumstances have been met. ${ }^{28}$

Finally, in 1984, Ray was adopted by the Washington Supreme Court in Martin v. Abbott Labs. ${ }^{29}$

The product line approach has been developed by the courts since its creation in California and its adoption in the above-mentioned jurisdictions. Therefore, it is important to take a brief look at some more recent decisions.

Two years after Ray, the Court of Appeals of California held in Rawlings that in order to apply the product line approach it is irrelevant whether the plaintiffs whe the purase of the e successor corporation $30 \mathrm{Also}$ irrelevant is the fact that the predecessor was a sole proprietorship, not a corporation. ${ }^{31}$ Moreover, the defendant had alleged in Rawlings that the product line had been terminated. The court considered the allegation not supported by the record, but, even so, note that the manner which the successor uses the predecessor's goodwill is not important to apply Ray. ${ }^{32}$ The manufacturing activity involves modification and even elimination of an unprofitable product line. Thus, the continuation of the business and its ability to spread those costs should be the focus, not whether a specific lin of products was discontinued. However, a different view maybe could be inferred from Ramire and Bussel.

In Bussel, the New Jersey Superior Court also decided that it is not necessary, in order to apply the new exception, that the purchaser had acquired all of the assets of the selling corporation. Also irrelevant are the changes in the manufacturing operations made as a result of technological advances. The plaintiff had been injured in 1980 when operating a radial arm saw manufactured by DeWalt Products Corporation (DPC), later DeWalt, Inc., that used to manufacture only radial arm saws. Thirty-on years before the accident, DeWalt had sold its assets to American Machine and Foundry Company (AMF) which expressly assumed liabilities and all obligations of the former and also created a new corporation named DeWalt, Inc. The old DeWalt changed its name to D-W, Inc. The second DeWalt, Inc. was later dissolved after the assignment of all its assets to AMF which continued to manufacture the arm saws through an unincorporated entity known as DeWalt Division of AMF. Another company, Black \& Decke had developed its own radial arm saw but it was not marketing it as it would like. Thus, Black and Decker decided to buy AMF's division. By doing so, Black and Decker would acquire a wellestablished name and product and also would be able to use the patents that had originally been obtained by DPC. Black \& Decker agreed "to be liable for all obligations, debts and liablities, both direct and contingent, of DeWalt of whatsoever nature and kind." ${ }^{34}$ AMF formed a new DeWalt, Inc., and transferred the stocks of the new subsidiary to Black \& Decker in exchange for stocks of the latter

The court held Black \& Decker liable. In doing so, the court stressed that it was not relevant that not all the assets originally transferred from DPC to AMF had been transferred to Black \& Decker, since the latter had acquired all the assets and information related to the manufacture of the radial arm saws. ${ }^{35}$ Furthermore, the court said that changes in the manufacturing operation, made as a result of technology, were not relevant to successor liability. In contrast, when dealing with cases of successor liability, the court should focus on the continuity in the manufacturing of the original manufacturer's product line throughout the history of the various asset acquisitions. ${ }^{36}$ The court relied mainly on the fact that the basic patented idea for the radial arm saw was still in use, that a distinguishing feature of the arm saw of the kind that had injured the plaintiff was still included in the arm saws, and that Black \& Decker was still manufacturing arm saws bearing the name DeWalt. The Bussel court also decided that it was not relevant that Black \& Decker had not caused the destruction of plaintiff's remedy. Causation, the court noted, has no relation with successor corporate liability. The reason to impose liability reposes on the benefit received by the successor as a result of the transaction ${ }^{37}$

The first observation, that it was not releant that not all the assets originally transferred from DPC to AMF had been transfered to Black \& Decker, is understandable, because one can imagine a transaction where not all the assets of the manufacturer are transferred to the successor corporation but, even so, the purchase was of a sufficient amount of assets that it resulted in the destruction of the plaintiffs remedy. Moreover, in a case involving successive transactions, one should focus on the original manufacturer's product line as a way to see how substantial were the transfers. It is also understandable that simple changes in the product line due to technological improvements are not enough to prevent application of the product line approach. But the court went further to say that causation was not necessary to apply Ray: that the transfer should not be the cause of the destruction of plaintiffs remedy. Furthermore, this would be true, according to the way the court reasoned, not only in cases involving successive transactions, but also where we have just one transfer of assets. However, one could read Bussel in a more restrictive way. The case involved 
successive purchase of the assets and the plaintiff was without remedy against the origina DPC, the original manufacturer. Thus, one could argue that the Bussel court held that where the plaintiff is without remedy against the origina manufacturer it is irrelevant if he has recourse against an intermediate successor.

When dealing with successive transactions, such a reading could have already been implied from the Supreme Court of New Jersey's decision in Nieves $v$. Bruno Sherman Corp..$^{38}$ In that case the court extended Ramirez to impose liability on an intermediate successor corporatio (Harris-Intertype Corporation) that had acquired the assets of the original manufacturer (T.W. \& C.B. Sheridan Companyl and after that had transferred those assets to its successor (Bruno-Sherman). The court stressed that Ray was concerned not with the availability of a particular viable successor, but with the unavailability of the original manufacturer as a result of the transfer of the assets. Thus, the court denied the order granting summary judgment to Harris and affirmed the order denying summary judgment to Bruno-Sherman because both could be liable for the injury suffered by the plaintiff. 39

The decision in Nieves indicates that to ap ply Ray when dealing with successive transfers of the assets the court is concerned only with the destruction of plaintiffs remedy against the original manufacturer, being irrelevant the existence of recourse against another successor

In California the courts have not read Ray in the same way, at least not in cases involving just one successor. In 1993 the Supreme Court decided Beatrice Co. v. Bd. of Equalization, ${ }^{40}$ case where a corporation had transferred all of its assets to a subsidiary, receiving shares issued by the latter as consideration. The subsidiary assumed also substantially all the liabilities of the parent company. The court observed that in Ray there was no indication that a change of ownership had occurred and the defendant company had held itself out as the same enterprise. Under these circumstances, the court noted, ability could be imposed on the acquiring corporation when the plaintiff had no recourse against the predecessor. On the contrary, liability could not be imposed on the successor where the injured party had recourse against the predecessor and the two corporations have con- tinued as separated entities. ${ }^{41}$ Not only is the destruction of plaintiff's remedy necessary to apply Ray in California, but the Court of Appeals decided that it is also necessary that some causation exist between the succession and the destruction of plaintiffs remedy. ${ }^{42}$

A similar result was reached by Washington Supreme Court in Hall v. Armstrong Cork. ${ }^{43}$ Hall involved UNARCO Industries, Inc a manufacturer of asbestos products. One of its pipe insulation. Although Pits burgh Coring pipe insulation. Although Pittsburgh Corning Corporation had acquired all the assets related to Unibestos, UNARCO had continued to manufacture and sell other asbestoscontaining products. Moreover, Pittsburgh had not held itself as a continuation of UNARCO. Thus, the court claims arising out of defective products manufactured by UNARCO. Even though there had been the sale of the product line, Pittsburgh had not purchased substantially all of the assets of UNARCO which continued to exist, manufacturing other products; Pittsburgh had acquired only the goodwill associated to Unibestos, not the goodwill the goodr the court said that to apply the product line approach it would be necessary that the plaintiff had lost his remedy against UNARCO, and that the loss had been caused by the purchase of the assets. ${ }^{44}$ The court went further to say that it could "discern no reason for extending the product line exception when the predecessor has duct line exception not been extinguished, in law or fact, by sucsion or dissolution." 4

Two other observations must be made about the product line exception. First, its application is limited in California to tort liability, as the Supreme Court stressed in Ray ${ }^{46}$ and Beatrice. ${ }^{47}$ Second, the Court of Appeals of California in Rawlings considered irrelevant, in order to apply Ray, the defendant's assertion that the product which had caused the plaintiffs injury had not been mass-produced by the predecessor, but had been manufactured in accordance with the plans and specifications of the owner ${ }^{48}$

Finally, I think that in Goncalves $v$. Wire Technology 49 the New Jersey Superior Court went too far in its application of the product line approach when it held that a purchaser of assets in a liquidation proceeding under a Chapter 7 of the Bankruptcy Code ${ }^{50}$ can be liable as a suc- cessor corporation. First, one of the arguments to impose successor liability in Ray was that the successor had destroyed the plaintiffs remedy. In a Chapter 7 case the predecessor is already defunct before the transfer of the assets. ${ }^{51}$ Second, one who buys something in a bankruptcy proceeding at least as a general rule. would have an of would have an open-ended proceeding, with successive acquisitions of the assets of the bankrupted estate and the respective assumption of liabilities with each purchaser assuming the remaining liabilities of its predecessor. The Goncalves court apparently failed to consider the basic idea that a liquidation proceeding exists mainly to distribute to tors their share of the amount of the debtor's property included in the estate, and to do this we have to transfer the property of the estate. The same transfer we could have when trying to enforce a judgement that awards damages for personal injury àrising out of a defective product. The defendant's property is the only guarantee the plaintiff has that he will receive the whole amount fixed by the court. If that property is not enough, the result is that the plaintiff will not receive the whole amount. And the one who eventually buys, in a judicial proceeding, some of the assets of the defendant, the proceeds of which sale are used to pay defendant's creditors will not be liable for the part of the indemnity that will not be paid. There is nothing different in a Chapter 7 case. The one who buys the assets of the estate cannot be liable as a successor, absent any other factor. ${ }^{52}$ One could say that the situation is different in a Chapter 11 case where the bankrupted is not already defunct as in a Chapter 7 case, but to impose successor liability where the purchase of the assets is made in a liquidation proceeding fractures the whole judicial system. A third argument to reject liability where the successor purchases the assets from a bankrupted predecessor was used by the Eighth Circuit in Tucker $v$. Paxson Machine Co 53 When the purchase is made under a liquidation proceeding the buyer does not have the ability to estimate the risks of claims for injuries arising out of previously manufactured defective products.

In sum, the rationales to apply the product line exception are:
1) the virtual destruction of the plaintiffs remedies against the original manufacturer as a result of the business acquisition:

2) the successor's ability to assume the riskspreading role of the original manufacturer and

3) the fairness of requiring the successor to shoulder a responsibility for defective products that was a burden obligatorily connected to the original manufacturer's goodwill being enjoyed by the successor in the continued operation of the business. ${ }^{54}$

It is irrelevant whether the plaintiffs injury occurred after or before the purchase of the assets by the successor corporation ${ }^{55} \mathrm{Also}$ iirelevant is the fact that the predecessor was a sole proprietorship, not a corporation. ${ }^{56}$

At least one decision of the Court of Appeals of California has decided that the product line exception can be applied where the product line has been terminated by the successor. ${ }^{57} \mathrm{More0}-$ ver, changes in the product line as a result of technological improvements are irrelevant. ${ }^{58}$ In those cases of successive purchase of the assets it is not relevant that all the same assets originally transferred from the original manufacturer to the first successor had been transferred to defendant. ${ }^{59}$

The destruction of the plaintiff's remedy against the original manufacturer must be caused by the purchase of the assets to apply Ray. ${ }^{60}$ However, where there is successive purchases of the assets it is irrelevant whether the plaintiff has recourse against an intermediate successor. ${ }^{61}$

At least in California the product line exception is limited to tort liability, ${ }^{62}$ and the Court o Appeals of the same state decided that the exception could be applied in a case involving a product that had not been mass-produced.63

Finally, in a decision that fractures the whole judicial system, the New Jersey Superior Court applied Ray in a case where the assets had been purchased in a Chapter 7 case. ${ }^{64}$

\section{The Continuity of the Enterprise Exception}

This exception resulted from an extension of two basic exceptions to the rule of no successor liability in case of purchase of assets: the de facto 
merger or consolidation exception and the mere continuation exception.

The de facto merger or consolidation exception has been applied in those cases where the companies enter an agreement that achieves the same results as a merger or consolidation but do not follow the legal steps required of a merger or consolidation. The courts have considered the following factors to assess the existence of a de facto merger:

a) continuity of the business enterprise between seller and purchaser, including continuity of management, employees, location and assets:

b) shareholders' identity:

c) dissolution of the seller or cessation of its activities as soon as practically and legally possible;

d) assumption by the buyer of those liabilities and obligations of the predecessor that are necessary for the uninterrupted continuation of the business. ${ }^{65}$

The mere continuation exception has been applied when the successor looks like a reorganized version of its predecessor and not like a new corporate entity. The factors considered by the courts when dealing with this issue are similar to those mentioned above and include:

a) identity of the same production facility in the same place;

b) continuity of employees and supervisory personnel;

c) production of the same product;

d) use of the same name

e) continuity of assets;

f) continuity of the general business operations;

g) whether the successor holds itself as a continuation of its predecessor ${ }^{66}$

Although some courts have emphasized, at least when dealing with a de facto merger, that it is not necessary to satisfy all the factors in order to find a de facto merger or consolidation, ${ }^{67}$ the identity of shareholders traditionally has been considered indispensable in a de facto merger or consolidation case, ${ }^{68}$ while the key point in a mere continuation case is the identity of management and ownership. ${ }^{69}$ It is easy to understand that traditional view. The first exception was created to deal with situations where corporations were entering by the "back door"70 into mergers. Since the identity of shareholders is an element of a merger, without this identity one could not say that there is a de facto. The mere continuation exception, on the other hand, was constructed to deal with those cases where the assets of one corporation were purchased by another company, both owned by the same would be nothing more than a reincarnation of the predecessor.

The decisions that will be discussed basically dealt with the question whether the de facto or consolidation exception, or the mere continuation exception should be expanded to include those cases of purchase of assets where there is no identity of ownership.

Cyr v. B. Offen \& Co., Inc. ${ }^{72}$ has been cited as the first case to expand the mere continuation exception. ${ }^{73}$ Actually, the reasoning in $\mathrm{Cyr}$ could also be considered the first case applying the product line approach. ${ }^{74}$ Cyr can be included under the present heading because Cyr was used as guidance in Turner $v$. Bituminous sualty $\mathrm{Co}^{75}$ which is an expansion of the de facto merger exception.

The First Circuit applied New Hampshire law in Cyr and assumed that the courts of that state would adopt an extension of the mere continuation exception. ${ }^{76}$ On October 20, 1969, the plaintiffs were injured when cleaning press rollers. They were inside the ovens into which the rollers directed the printed paper for drying when the gas-fired burners ignited. The solvent that was being used in the roller cleaning exploded. As a result, both plaintiffs suffered serious burns, and one of them died two weeks later.

The press had been designed, manufactured and sold by B. Offen Company, a sole proprietorship owned by Bernard Offen. After his death key employees continued to run the business, and the enterprise was finally sold to them and an outside investor in 1963. B. Offen \& Co., Inc. was then created and assumed the service obligations of the proprietorship, continued to service and renovate old dryers, including those of the kind involved in the accic accident, and purchased the assets of the predecessor. Moreover, no notice was given to customers that a new or di-
fferent business was beginning.

The court relied mainly on the continuation of the business test and held $\mathrm{B}$. Offen \& $\mathrm{Co}$.
Inc. liable. Under these circumstances the dictates of freedom of business to terminate an enterprise are less compelling than they had previously been. Moreover, two of the policies of imposing strict liability could be used to justify the successor liability. First, assuming the ongoing business, carrying on the experience and expertise of the predecessor, the successor is in a better position to gauge the risks and costs of meeting them. That is because the latter knows the product, can calculate the risks, obtain insurance and spread the cost of these among consumers. Second, the successor is able to improve the quality of the product. The imposition of liability would be an incentive to do this. ${ }^{77}$

Turner v. Bituminous Casualty Co., decided by the Michigan Supreme Court in $1976,{ }^{78}$ can be considered the leading case about the continuation of enterprise exception. Charles Turner had been injured by a power press manufactured by T.W. \& C.B. Sheridan Company (Old Sheridan). Five years before, Harris-Intertype Corporation had purchased the entire business of Old Sheridan, including its goodwill, name and assets. Following the transaction. Old Sheridan changed its name and Harris created a subsidiary, T.W. \& C.B. Sheridan Company (New Sheridan) which was designated to receive the assets of Old Sheridan. New Sheridan and Harris signed an agreement upon which the former assumed Old Sheridan's liabilities. Old Sheridan was dissolved following the payment by Harris and its distribution to the former's shareholders. Finally, New Sheridan was merged with Harris.

The court reversed the decision of the circuit judge that had granted the motion of defendants for summary judgment, holding that they were not liable for claims arising out of defective product that they had not manufactured, sold or distributed. Deciding the case, the Supreme Court first observed that the traditional rule of no successor liability and its exceptions were developed because the courts were concerned with tax assessments, creditors' protection or shareholders' rights. As a result, that rule and its exceptions could not meet the problems related to products liability torts. ${ }^{79}$ The court noted that it would be illogical, all the other factors being equal, to allow product liability recovery when the purchase of assets is made for stock and to not allow recovery when the acquisition is made for cash. The absence of continuity of ownership should not be decisive because the stockholders of the seller could receive just a small quantity of stock in the new corporation or the continuity could be more symbolic than real. Likewise, the need for identity of shareholders would permit, in those cases where there is no real business reason for choosing a cash acquisition, the use of the corporate law for purposes neither really intended for it, nor in the public interest. ${ }^{80}$

New Sheridan had tried to incorporate Old Sheridan into its system with as much of the same structure and operation as possible. The maintenance of Old Sheridan's goodwill, product, personnel and policy would help New Sheridan to retain the former's clients and acquire new clients attracted by the established reputation. Under these circumstances, "to say Old Sheridan is a stranger to New Sheridan, and vice versa, is to honor form over substance." ${ }^{\text {"1 }}$ Since continuity had been New Sheridan's purpose, this should be the key fact considered by the court. ${ }^{82}$ The court went further to say that justice would be offended if a company that holds itself out as a particular corporation for purpose of sales, was not stopped from denying that it is that corporation for the purpose of determining product liability. 83

Finally, the Michigan Supreme Court announced its test to assess the enterprise continuity. When dealing with this issue, the factfinder should consider basically the same factors analyzed in a de facto merger case except the identity of ownership. Accordingly, the court should consider:

a) whether there was continuity of the business enterprise between seller and purchaser, including continuity of management, employees, location, assets, business operations and trade name;

b) whether there was the dissolution of the seller or the cessation of its ordinary business as soon as practically and legally possible and

c) whether there was the assumption by the buyer of those liabilities and obligations of the predecessor that were necessary for the uninterrupted continuation of the business. ${ }^{84}$ 
These factors are not requirements but only guidelines to be used by the courts when assessing the identity of an enterprise. Thus, continuity of the predecessor corporation and its dissolution are not prerequisites to apply the exception as decided by the Michigan Court of Appeals in Haney v. Bendix Corp. ${ }^{85}$

In 1980, the same Court of Appeals decided that the continuation of the enterprise exception could not be applied where both the predecessor and the successor were sole proprietorships and the successor had not held itself out as a continuation of the predecessor. ${ }^{86}$ The court noted that a corporation cannot avoid liability by altering its form although retaining the business. Thus, the successor liability was developed to mitigate the effects of this kind of practice. In this case, however, the predecessor had not been dissolved, and neither the management or control had remained the same. Moreover, the trade name had been used only for a short time. The court not only found that not all the factors required in Turner to show a prima facie were present, but it stressed that there was no case in Michigan imposing successor liability in a noncorporate situation such as the one found in the case. ${ }^{87}$

When deciding Fenton Area Public Schools $v$. Sorensen-Gross Construction Co. ${ }^{88}$ in 1983, the same court applied Turner's guidelines. In the same year the Supreme Court of Alabama applied Turner in Rivers $v$. Stihl, Inc. ${ }^{89}$ In this case, one of the plaintiffs had been injured when operating a Stihl chain saw distributed by Stihl American, Inc. The latter had been substituted by Stihl, Inc. as exclusive distributor of Andreas Stihl's products in the United States. The case was relatively simple because Stihl, Inc. had entered into an agreement with Stihl American, Inc. upon which the former had assumed liability for products liability claims arising out of Stihl products previously sold by Stihl American. Even so, following Turner, the court adopted a "basic continuity of enterprise" test and held Stihl, Inc. liable because the totality of the transaction demonstrated a basic continuity of the enterprise..$^{90}$ The court relied on the fact that Stihl, Inc. had acquired all the predecessor's assets and the exclusive rights in the United States to the Stihl trade name, and had been assigned American's contract rights. Moreover, the court relied on the assumption of liabilities by Stihl, Inc. and stressed that the lack of use of predecessor's plant and the employment of all Stihl American's, Inc. employees were not controlling factors, "since exactly the same products manufactured by the same manufacturer were being distributed in the same market under the same trade name. ${ }^{n 91}$

More recently, Turner was applied in Thompson v. Mobile Aerial Towers, Inc. ${ }^{92}$

\section{THE ARGUMENTS AGAINST TURNER AND}

\section{$R A Y$ AND THE ANAIYSIS OF THE ISSUE}

The majority of the jurisdictions have not folowed either Ray or Turner. ${ }^{93}$ We are going to take a look at some decisions and the arguments that have been used to reject both exceptions.

Ray was decided in 1977. In the same year, the Seventh Circuit refused to apply Ray in a case involving the Wisconsin law. ${ }^{94}$ The court stated that the adoption of the product line exons on society and the courts are ill-equipped to balance the equities among future plaintiffs and defendants. ${ }^{95}$

This is really a strong argument against the extension of the four traditional exceptions, but we cannot forget that the rule of no successor liability and its exceptions were a creation of the courts. Thus, the courts that are now refusing to make any change in the traditional rule are the same courts that had created it before the adoption of the strict liability principles. ${ }^{96}$

The Supreme Court of Florida rejected both approaches in Bernard v. kee Manufacturing Co. ${ }^{97}$ The plaintiff had been injured by a defective lawn mower manufactured and sold by Kee Manufacturing Company. The accident occurred in 1976. The plaintiff sought relief against Kee, Inc. which four years prior to the injury had acquired the manufacturing plant, inventory, goodwill, and the trade name from Flechas J. Kee, who had done business as Kee Manufacturing Company. After the purchase Kee, Inc. continued to use the same manufacturing process, the assets bought were used to manufacure the lawn mowers, and the factory personnel was maintained. Moreover, Kee, Inc. continued to provide replacement parts for the same model of lawn mower that was used by the pla- intiff, and Kee's, Inc. brochure stated that it had been manufacturing lawn mowers since 1948 while the transaction occured in 1972 .

The court decided not extend the general rule of successor liability because it would threaten small businesses. According to the court, cor porate acquisitions would be discouraged as a result of business planners' fears of liability. Consequently, instead of having more ownership transfers we would have more companies going into liquidation, and would decrease the number of small companies being replaced by other successful small corporations. The net result of that would be the decrease of the small and the increase of the large manufacturers with a greater centralization of business; a bad result for the United States. ${ }^{98}$ The court also relied, to re ach the same conclusion, on the difficulty and high costs that a small business would have in obtaining products liability insurance for defect in a predecessor's product. ${ }^{99}$ Furthermore, the extension of the liability to the successor in cases of purchase of assets would not be consistent with one of the policies of the strict liability that is to make the manufacturer that put the product into commerce to be responsible for the injuries resulting from a defective product. Since the successor has not put the product int commerce, neither has invited its usage nor im plied its safety, the successor was never in a position to eliminate the risk. ${ }^{100}$

Six years later the Court of Appeals in Florida applied Bernard in Safarik v. Garrison Bight Marina. Inc. ${ }^{101}$

The first argument in Bernard is not convincing. The existence of liability in a merger case is something that has to be considered by the parties involved when deciding wheter to enter into an agreement. But, it seems, this factor alone was neither responsible for more small com panies going into liquidation nor for the reduction in the number of mergers. We have already seen and we still see many such transaction nowadays. ${ }^{102}$

The same could be said about the difficulty and high costs that small business would have in obtaining products liability insurance. In addition, the difficulty or high costs involves in obtaining insurance were never conceived as arguments to free somebody from their liability when they have caused an injury, for example.
The question is not who can get insurance or whether it would be difficult or not. The point is to know who should be liable. Moreover, high or low cost is something always considered and present in any kind of business, the whole competition that exists in a free market economy is entirely based on the ability of the competitors to produce with lo are always going to have companies with lower and companies with higher costs and the reduction of the costs is something that should be pursued by the businessmen. That is the market rule! Otherwise, why should one care about antitrust law? Moreover, whether small corporations are at a definite disadvantage visà-vis larger competitors in passing through the cost of liability insurance, ${ }^{103}$ this is not enough to avoid liability. Economy of scale is not condemned by the law, neither is the fact of being a big corporation. Another argument, mentioned in Ramirez, ${ }^{104}$ that could have some relation with the reasoning in Bernard is that ring corporation to reduce the price of the transaction. But this would result, in fact, in a more accurate measure of the true worth of the business. ${ }^{105}$ How to evaluate the business is something that should be left to businessmen and even if it were difficult to assess the risk of liability, those who want to buy a business generally have an idea about how much they are willing to pay for it

The third argument used by the court seems to be irrefutable. The consequence is that one cannot base the successor liability on the same reasons that had supported the strict liability. The same argument was also used also in the next case which we are going to look at.

Turner and Ray were also rejected by the Court of Appeals of Illinois in Nguyen v. Johnson Machine \& Press Corp. ${ }^{106}$ In 1978, Manh Hung Nguyen suffered severe injuries to his hands from a punch press manufactured by Bontrager Corporation. The same kind of press had been previously manufactured by Johnson Machine and Press Company that had transferred all its assets and liabilities to Bontrager. Although transacting no business as a manufacturing entity, Johnson had continued to exist after the transaction as a Bontrager wholly owned subsidiary. In 1962, Amsted Industries, Inc. bought 
all the assets of Bontrager including the assets of Johnson as a way to use the Johnson trade name. Bontrager and Johnson were dissolved after the buy-and-sell agreement. Amsted continued to manufacture the same kind of press through a wholly owned subsidiary, South Bend Lathe, Inc. This subsidiary was later transformed in to an unincorporated division of Amsted. In 1975, Amsted sold the Johnson press ted. In 1975 , Amsted so line to LWE, Inc. which further changed its name ted agreed to indemnify LWE, Inc. for claims arising out of defective Johnson presses. ${ }^{107}$

The court started by noting that both Ray and Turner were not clear whether they were imposing liability on the successor on its own. or whether they were imposing liability because the successor corporation should assume the potential liability of the predecessor. If the former, the court was unwilling to impose liability in the corporate successor where it had not created the risk of injury. If the latter, the corporate principles should guide the decision and a change in the corporate rules should be made. In this case, the question would not be whether to apply the corporate law or the strict liability law, but whecorporate law or the strict liability law, but whe-
ther a change in the corporate law should be ther a change in the corporate law should be
made based on the principles of strict liability. ${ }^{108}$ When dealing with that issue, one should not misapprehend the importance of the continuity of shareholders, and the separateness between the legal entity and its stockholders. The shareholders are the ones that ultimately enjoy the profits and suffer the losses. Since in a merger the assumption of liability is justified because one corporation is carried over into the other and its shareholders become security holders of the successor corporation, they should not be allowed to enjoy the continuing profits at the same time that they escape liability. ${ }^{109}$ But why did the court stress the separateness between the legal entity and stockholders and later rely on the identity of shareholders to justify the imposition of successor liability in a merger? If the key point is the separateness, then the identity of sharcholders should not be important to impose liability. On the con portant to impos liability. On the contrary, if the key point is the identity of ownership, why did the court emphasize the separateness between the legal entity and its shareholders? Moreover, why did the court emphasize that suc- cessor and predecessor were two separate entities? If it were solely because they did not have the same shareholders, then the court was negating the separateness, because one entity is not the same as the other just because both have the same shareholders. Maybe the court did it because it relied on the fact that in a merger one corporation is carried over into the other, while the key point to be considered in a merger should be the fact that the patrimony of one corporation is carried over into another; a patrimony formed by the whole mass of existing or potential rights and liabilities attached to the corporation. That is, or at least should be, the main rationale to impose liability in a merger case.

The court went on to say that in a purchase of assets case the seller corporation remains with the cash to meet whatever liabilities, and the buyer corporation should not be liable after having paid a substantial price for the predecessor's assets. Moreover, that the consumer has no remedy against the predecessor cannot be a reason to impose liability on the successor corporation. This is merely a statement of the problem. The consumer has no remedy because of the corporate law. The observation is correct but the court should have gone further, to see that the issue in the case was exactly the change of the corporate law; the same corporate law that was created by the courts. Although we know as the judge said in the Auden's poem that "law is "law is ion about whether one should change the law just by saying that the "law is". The question is not only about what the law is, but if the law should continue to be as it is. To answer this question, as we are going to see further, the court needs to focus, not on whether the predecessor received adequate consideration for the transfer of the assets, but on what the object of the transaction was.

The court also noted that one of the reasons to impose strict liability is to impose the costs of the liability on the manufacturer that is in a better position to gauge the risks, get insuran, angh sre though, there were some studies, the court noted, indicating that some manufacturers are not able to get insurance, ${ }^{111}$ they still could make a kind of self insurance and spread the cost among consumers. And even if that was not possible. still the main reason to impose strict liability would be valid, the manufacturer shall be liable because it creates the risk of injury, because it put the defective product into commerce, becau se it has a duty to prevent injury. 112 This rationale could not be used to impose successor cor poration liability because the successor did not put the defective product into the stream of commerce. Thus, to impose liability on the successor based only on the ability to bear the costs one should be sure about whether the successor had placed the defective product into the stream of commerce. To determine this issue the legislature is in a better position than the courts. We have already discussed these arguments.

Finally, the court stated that the enjoymen of accumulated goodwill was not enough justification to impose liability on the successor corporation, and if it were, then the liability should not be restricted to cases of liability arising out of defective products. ${ }^{113}$ The court did not ex plain why the transfer of goodwill should not be enough, but the latter observation seems to be correct since we find no logic to have a different rule in cases of liability not arising out of a defective product.

The Wisconsin Supreme Court also rejected the extension of the traditional exceptions bu was contradictory in its decisions. In July, 1982 the court decided Tift $v$. Forage King Indus. Inc. ${ }^{114}$ On October 4, 1975, Calvin Tift was injured while operating a tractor with a defective chopper box attachment used for cutting and removing silage. The defective chopper box had been manufactured by a sole proprietorship doing business under the name of Forage Kin Industries. After the date when the chopper box had been manufactured the owner of the business formed a partnership converted later into a corporation. The former owner and another man were the only stockholders of the company that retained the same employees, continued to manufacture the same products and to use the same dealers as before. In the same year of the creation of the corporation the former owner bought the stocks of the other shareholder. Finally, some years later he sold his stocks to Tester Corporation.

The court first held that the successor can be liable under the traditional corporate rule even when the predecessor is a sole proprietor- ship. 115 The court noted then that the de facto merger or consolidation exception and the mere continuation exception were developed to deal with those cases where the successor's business is basically the same as the business prior developed by the predecessor. When the court faces a situation like that it must just determine that the defendant is essentially the same as the original manufacturer despite the business transformations. ${ }^{116}$ Finally, the court reversed the summary judgment dismissing the complaint because Forage King Industries, Inc. had acquired all the assets of the former proprietorship, and had continued to manufacture the same product, under the same manufacturing operation. Under these circumstances, Forage could not be considered as a matter of law, free of any possible liability. Furthermore, Forage's liability should not be dependent on the existence or not of recourse against the former proprietorship. ${ }^{117}$

It seems that the court adopted, in this case the continuity of enterprise exception. ${ }^{118}$ But maybe the court was not adopting any of the two exceptions which we are discussing in this essay. Instead of this, the court was just stressing that a sole proprietorship cannot avoid liability by creating a corporation to run his business. In this sense, the corporation would be a mere continuation of the predecessor business organization. If we read Tift in this way then the decision could possibly make some sense when compared with the following cases that we are going to deal with. If we do not, then they are really contradictory. 119

On the same day when the court decided Tift the court also decided Cody v. Sheboygan Machine Co., ${ }^{120}$ a case where the court found that the facts did not demonstrate any continuity or identity of business organizations. In Cody, the plaintiff had been injured while operating a drum sander manufactured by Sheboygan Machine Company (Sheboygan I). Seventeen years before the accident Sheboygan Locke, Inc. had bought all the Sheboygan I's assets which changed its name to Allester. Sheboygan Locke, Inc, by its turn, had changed its name to Sheboygan Machine Company, Inc. (Sheboygan II). There was no common identity of managers and shareholders between the two companies. Five years before the accident Sheboygan II had sold part of 
its inventory and assets to Monitor Machine Company, Inc. The buy-and-sell agreement in cluded real estate, customers lists, good will and trade name. Sheboygan II adopted its old name and Monitor changed its name to Sheboygan Machine Company, Inc. (Sheboygan III).

Sheboygan III had never manufactured sanders before the accident and neither had Shegoygan II done so. Instead Sheboygan III had been a job shop, doing repair work and fashioning replacements, and had manufactured parts for a variety of machines, including the Sheboygan sanders. Under these circumstances, th court held that Sheboygan III could not be liable because it had only its name and place of business in common with the original manufacturer. In sum, there was in the case, no identity of business organizations.

Finally the Wisconsin Supreme Court decided Fish v. Amsted Indus., Inc. in 1985, ${ }^{121}$ a case involving the same companies as in Nguyen. ${ }^{12}$ Tift had not been a unanimous decision and one of the dissenting judges wrote the opinion of the court in Fish.

The court interpreted Tift as applying the traditional rule of successor liability. While refusing the direct application of the de facto mer ger or consolidation, and the mere continuation exceptions when a soleproprietorship is involved, the Tift court had considered that the suc cessor was the same business organization as the predecessor ${ }^{123}$ Actually, the court in Fish was just playing with words so as to justify its decision without overruling Tift. Let us assume, as the court said in Fish, that Tift had held that direct application of the de facto merger or consolidation, and the mere continuation exceptions were not possible in a case involving a sole proprietorship. But then the court applied a different concept, the idea of "common identity" or "same business organization". In this case, the Tift court definitely did not apply the traditional intercorporate rule of nonliability with its four exceptions. Instead, the court applied in Tift a fifth exception. If we do not read Tift in this way, then we must recognize that the decision extended the mere continuation exception while applying it in a case involving a soleproprietorship. In this case, the Tift court did not hold that direct application of the de facto merger or consolidation, and the mere continuation exceptions is impossible when a sole proprietorship is involved. As you see, the Wisconsin Supreme Court constructed a fallacy in Fish as a way to make a strict application of the traditional rule of liability. Any way, the court affir med an order granting summary judgment because there was in the case neither identity of ownership nor identity of management. Moreover, the court noted that broad public policy decision in actions based on product liability law would be better made by the legislature, an argument already discussed in this essay. Finally, the court refused to adopt the product line or the continuation of enterprise exceptions. ${ }^{124}$ As in Tift the decision in this case was not unanimous.

The New York Court of Appeals addressed the issue of successor liability in Schumacher $v$. Shear $\mathrm{Co}^{125}$ and granted a motion for summary judgment. The court relied on its previous decision in Hartford Accident \& Indemnity Co., Inc v. Canron, Inc., ${ }^{126}$ a case where liability was re jected because none of the four traditional exceptions to the rule of no successor liability wa found. Thus, the court in Schumacher basically granted the motion applying the traditional rule and its four exceptions. ${ }^{127}$ But the court also went further to say that the facts of the case did not allow application of the new exceptions. First there was not identity of management, key personnel and phys id tors under Turner. Second, the predecessor haccessor had not been dissolved shortly after the acquisition of its equipment, and the successor had not used essentially the same factory, name and office personnel after the transaction to produce the same product. Thus, the facts of the case were distinguishable from those in Ray. ${ }^{128}$

The product line and the continuity of enterprise exceptions were also rejected by the Su preme Court of Vermont in Ostrowski v. HydraTool Corp., a case judged in $1984 .{ }^{129}$ In Maryland, the continuity of enterprise exception was rejected by the Court of Appeals in Nissen Corp. v. Miller. ${ }^{130}$ The court noted that the successor se liable if he did not put the defective product in the market. Furthermore, it would not be fair to require the successor to bear the cost of unassumed and uncontemplated products liability claims essentially because he is still doing business and is considered as a "deep pocket". ${ }^{131}$ The first argument was already analyzed and we agree with the second. Further, an extension of the traditional exceptions was also refused in Lesane $v$. Hillenbrand In dus. ${ }^{132}$

Other arguments have been used against the adoption of the new exceptions. One of them was pointed out in Turner, ${ }^{133}$ the surprise faced by the successor in the case of a change in the law. The argument had already been used in Cyr and the First Circuit noted that "this kind of surprise is endemic in a system where legal principles are applied case by case and is no more an in justice than was the retroactive application of the strict liability doctrine in Stephan $v$. Sears, Roebuck \& Co., 110 N.H. 248, 266 A.2d 855 (1970)."134

Another argument used against the adoption of Ray and/or Turner is that liability under those cases would result in a windfall to the plaintiff who has been given a remote additional party to sue. ${ }^{135}$ However, the same windfall exist in a merger case. Moreover, the same windfall could occur on the regular course of business. The corporation can lose or make money in the regular course of its business and sometimes get extra and great profits as a result of some investment.

Others say that the profits earned during the original manufacturer ownership should bear the burden of liability for damages growing out of defective products. ${ }^{136}$ But when dealing with liability the law makes no difference if the tortfeasor got the money after or before manufacturing the product. Why should we make the distinction in a case involving successor liability? Since we focus on the continuity of the ongoing business there is no reason for that.

As you see, the courts rejecting both the product line exception and the continuity of enterprise exceptions do not offer convincing reasons why the exceptions to the rule of no successo liability should not be extended. However, they seem to be correct when they stress that the reasons used to impose strict liability cannot be used to impose successor liability. The observation is true, as we saw, when we think about the rationale of making liable the manufacturer that put the defective product into the stream of commerce, and is also true when we think about the idea that liability would make the manufac- turer improve the product. In a successor liability case this result could be obtained making the successor liable for future claims, not claims arising out of defective products manufactured before the transaction. Actually, improvement of a product line has no relevance to injuries caused by products marketed before the transaction as pointed out by Justice Callow in his dissenting opinion in Tift. ${ }^{137}$ The spreading role of the manufacturer, a rationale many times used to justify strict liability, was analyzed supra.

Let us take a look now at the arguments used by the courts to apply the product line exception and the continuity of enterprise exception Ray considered basically three factors:

1) the virtual destruction of the author's remedies against the original manufacture as a result of the business acquisition;

2) the successor's ability to assume the riskspreading role of the original manufacturer; and

3) the fairness of requiring the successor to shoulder a responsibility for defective products that was a burden obligatorily connected to the original manufacture's goodwill being enjoyed by the successor in the continued operation of the business. ${ }^{138}$

First of all, one cannot be really sure about the necessity of all the factors to apply the product line approach. Although some courts have suggested that the key point should be the benefit received by the successor, others have stated that the existence of the three circumstances mentioned in Ray must be met to apply the exception. ${ }^{139}$ It seems unreasonable to subordinate liability to the existence of recourse against the original manufacturer. The lack of recourse can result from the manufacturer's regular course of business, but this is not enough reason to impose liability on someone else. The successor should be liable because of its acts. The argument that the transaction destroyed the plaintiffs remedies against the predecessor is not correct since we are assuming that adequate consideration was given. ${ }^{140}$ Thus, it is not the purchase of assets but some subsequent act that in fact destroys the consumer's remedies. Let us say, for instance, that after the sale of its assets the original manufacturer continued to exist for two years and finally was dissolved. 
Since adequate consideration was given, the destruction of consumer's remedy was a result of the dissolution, not of the buy-and-sell agreement. The same example can be used to show why any imposition of successor liability could not be conditioned to the "immediate" or "as soon as possible" dissolution of the selling corporation. The predecessor corporation can survive the transaction as a hollow shell

The second rationale in Ray seems to be even less convincing. The successor should not be liable because it can more easily assume the riskspreading role of the original manufacturer. The successor should be liable because it made something that resulted in the injury. In the case of strict liability arising out of defective products the manufacturer is liable because it puts a defective product into the stream of commerce. It does not matter if it is able to spread the cost among consumers. Actually, this is not a good question to be made in torts cases. Instead o asking who can more easily spread the costs, one should ask who should bear the costs. Moreover, the manufacturer does not always have the means to spread that cost or find itself in better position to do it. That can be the case where a small manufacturer sells its product to a big corporation. But the manufacturer certainly has the means to avoid entrance into the stream of commerce of a defective product. For the same reasons we do not accept as relevant the argument that the successor is in the same position as was the predecessor to estimate the risks. And definitely we reject the argument that the manufacturer is "in a better position both to judge whether avoidance costs would exceed foreseeable accident costs and to act on that judgment." 141 This argument would exonerate the tortfeasor if he can prove that the costs to avoid the accident were higher than the amount of the injuries. No reasonable law system can accep this!

The best argument in Ray seems to be the third one, the fairness of requiring the successor to shoulder a responsibility for defective products that was a burden obligatorily connected to the original manufacturer's goodwill being enjoyed by the successor in the continued operation of the business. Let us imagine a wholly owned subsidiary. If somebody buys the stocks of such a company he will assume exactly the same position as former owner, control the enerprise, have exactly the same ongoing business. The result of that is that the same company will still be liable for its debts and any claim arising out of defective products. But let us say that the buyer still wants to buy the enterprise but does not want to assume its debts and liabilities. In this case the buyer should purchase only the assets of the corporation, more chas only the assets of the corporation, more the whole business but not assume the legal entity. The question then should be whether the legal system should allow this kind of transaction with this effect. The only difference between both agreements is that in the second the buyer does not become the controller of the legal entity. But should this fact alone justify liability in the first case and no liability in the second? The buyer did not get exactly what he was looking for: the ongoing business? Moreover, if we consider a merger case when just a small group of shareholders of the original manufacturer get a small quantity of stocks in the successor corporation, should it be enough to justify liability in a merger case and not in a case involving the purchase of substantial all of the assets of the corporation where the price is paid in cash? The whole idea of a corporation is to permit the shareholders to set up a business without being liable with all of their patrimony. A completely different thing is to use the corporate veil to sell an ongoing business with more profit because the owner can transfer it without liability. This results in the use of a legal entity for purposes that were not pursued by the legislator. Despite the fact that literally speaking there would be no problem with this situation, we have known for some time that the courts have questioned the use of legal institutes for purposes, other than those for which the institute had been created. The "piercing the corporate veil" doctrine is an example of this.

We really think that in cases of purchase of assets the courts should focus on the object of the agreement. So far as the buyer purchases the ongoing business it should be liable for claims arising out of defective products manufactured by the original manufacturer. That is because an ongoing business is composed not only by the assets. Instead of this the ongoing business is formed by the assets and the liabilities related to it. That puts the emphasis on the en- terprise and not on the legal entity, which is also more appropriate to modern jurisprudence. ${ }^{142}$ The continuity of the enterprise not of the legal entity is the co entity is the concern in a chapter 11 case; the managers shall act for the benefit of the enterprise, not only for the benefit of the shareholders.

In sum, it is not fair to allow the purchaser to enjoy the manufacturer's goodwill without requiring the former to shoulder a responsibility for defective products that was a burden obligatorily connected to the referred goodwill. If not always, in most cases what makes the buyer purchase the assets instead of just set up a new business is exactly the possibility to benefit from the goodwill. Moreover, when the buyer represents itself as being the continuation of the original manufacturer it would also be unfair to allow it to deny this fact for purposes of products liability. ${ }^{143}$

In Cyr the court basically adopted two arguments that we have already discussed: the successor is in a better position to gauge the risks and costs of meeting them; the successor is able to improve the quality of the product. The Tur ner court, on the other hand, stressed that when there is continuity of there is cont deny liability only because there is no identity of ownership, a statement that we agree with. The exclusion made by Turner of the identity of ownership as a requirement to recognize liability had the result of focusing the new exception on the continuation of the business operation instead of continuation of managem nership as in the traditional de facto merger or consolidation, or mere continuation exceptions. ${ }^{14}$

To assess the continuation of the enterprise the Turner court said that one should conside the other factors usually used to apply the traditional de facto merger or consolidation exception:

a) whether there is continuity of the business enterprise between seller and pur chaser, including continuity of management, employees, location, assets, business operations and trade name;

b) whether there was the dissolution of the seller or the cessation of its ordinary business as soon as practically and legally possible and c) whether there was the assumption by the buyer of those liabilities and obligations of the predecessor that were necessary for the uninterrupted continuation of the business. ${ }^{145}$

The dissolution of the selling company cannot be decisive for the reasons stated supra. The other factors can be used but they should not be seen as necessary to find continuation of the enterprise. We agree with the assertion made by the court in Dawejko ${ }^{146}$ that it is preferable to phrase the new exception in general terms, allowing the courts to assess the existence of contiwing the courts to assess the exise by case basis.

\section{CONCLUSION}

When dealing with defective product liability some courts have expanded the exceptions to the traditional rule of no successor liability. Two new exceptions have been developed: the product line and the continuity of enterprise excepions.

However, the majority of the courts still apply the traditional rule with its four exceptions As a result of the difference in the law between the states, liability of the manufacturer will depend on the law to be applied in each case, creating undesirable uncertainty.

In those cases where the purchaser corporation buys not only the assets of the origina manufacturer but its ongoing business, the suc cessor should be liable. The limitation of liability to those cases where there is identity of ownership would result in the use of the legal entity for purposes that were not pursued by the legislator.

The assessment of the object of the transfer whether it included an ongoing business, should be made by the courts on a case by case basis.

\section{REFERENCE NOTES}

1 A collection of cases invoking the general rule ca be found in the dissenting opinion in Turner $v$. Bituminous Casualty Co., 397 Mich. 406, 434 n.1 (1976) See also, 15 Fletcher, Private Corporations, sec. 7122 $\mathrm{n} 1$. Nissen Corp. v. Miller, 323 Md. 613, 617 (1991); Hall
v. Armstrong Cork, 104 Wash. 2d 258, 262 (1984); 
Rivers v. Stihl, Inc., 434 So. 2d 766, 771 (Ala. 1983); Bernard v. Kee Mfg. Co., 409 So. 2d 1047, 1048 (Fla. 1982); Tift v. Forage King Indus., Inc., 108 Wis. $2 d$. 72, 75-6 (1982); Ramirez v. Amsted Indus., Inc., 86 N.J. 332, 340-1 (1981); Ray u. Alad Corp., 19 Cal. 3d 22, 28 (1977); Nguyen v. Johnson Machine \& Press Corp., 104 Ill. App. 3d 1141, 1143 (1982); Dawejko
v. Horgensen Steel Co., 290 Pa. Super Ct. 15, 18 v. Horgensen Steel Co., 290 Pa. Super Ct. 15, 18
(1981); Leannais v. Cincimnati, Inc., 565 F.2d 437 . (1981): Leannais v. Cincimati, Inc., 565 F.2d 437,
439 (7th Cir. 1977); 15 W. Fletcher, Cyclopedia of the Law of Private Corporations sec. 7122, at 231 (rev. perm. ed. 1990); Jerry J. Phillips, Product Line Continuity and Successor Corporation Liability, 58 N.Y.U.L.R. 906, 908 (1983)

3 Ramirez u. Amsted Indus., Inc., 86 N.J. 332, 34 (1981). This exception is sometimes included by See, for exas a part of the himsteur exceptions. Se. 332,341 (1981): Ray u. Alad Corp. 19 Cal. 30 22, 28-9 (1977).

4 Nichols v Roper-Whitney Co, 843 F. Supp 799,803 (D.N.H. 1994): Cyr v. B. Offen \& Co., Inc. 501 F.2d 1145, 1152 (5th Cir. 1974).

5 Ramirez v. Amsted Indus., Inc., 86 N.J. 332, 342 (1981); Nguyen v. Johnson Machine \& Press Corp. 104 IIl. App. 3d 1141, 1143 (1982); Leannais v. Cincinnati, Inc., 565 F.2d 437, $439-40$ (7th Cir. 1977): Phillips, supra, note 1, at 909. But see, Ray v. Alad
Corp., 19 Cal. 3d 22, 28 (1977)(consideration should consist wholly of stocks.

6 Ramirez v. Amsted Indus.. Inc., 86 N.J. 332, 342 (1981);Ray v. Alad Corp., 19 Cal. 3d 22, 29 (1977) Hill v. Trailmobile. Inc., 412 Pa. Super. Ct. 320,327 (1992); Dawejko v. Horgensen Steel Co., 290 Pa. Super Ct. 15, 19 (1981); Leannais v. Cincinnati, Inc., 565 F.2d 437, 440 (7th Cir. 197)

7 Korzetz v. Amsted Indus.. Inc., 472 F. Supp. 136 (E.D.Mich.).

Hernandez U. Johnson Press Corp., 70 Ill. App. 3d 664 (1979)(although apparently applying the mere continuation exception).

(1) Ramirez v. Amsted Indus., Inc., 86 N.J. 332 (1981) App. 3d 1141, (1982).

11 Fish v. Amsted Indus., Inc., 126 Wis. 2d 293 (1985).

12 See, Tracey by Tracey u. Winchester Repeating Arms Co., 745 F. Supp. 1099, 1111 (E.D.Pa. 1990)(citing other cases); Sullivan v. Joy Mfg. Co., IO N.Y.2d 806 blish a "special relationship")

13 Id. at 1112

14 Travis v. Harris Corp., 565 F.2d 443, 449 (7th Cir 1977): LaFountain $v$. Webb Indus. Corp. 759 F. Supp. 236, 243 (E.D.Pa. 1991)(citing other cases)

$15 \mathrm{See}$, about the duty to warn, LaFountain $v$. Webb dus. Corp., 545 F.2d 544 (3rd Cir. 1991); Leannais v. Cincinnati, Inc., 565 F.2d 437 (7th Cir. 1977); Travis v. Harris Corp., 565 F.2d 443 (7th Cir. 1977); Nichols v. Roper-Whitney Co., 843 F. Supp. 799 (D.N.H.
1994); LaFountain v. Webb Indus. Corp., 759 F. Supp. 236 (E.D.Pa. 1991): Tracey by Tracey v. Winchester Repeating Arms Co., 745 F. Supp. 1099, 1111 (E.D.Pa. 1990); RICHARD A. EPSTEIN, CASES AND MATERIALS ON TORTS 692-715 (Little, Brown and Co., 5th ed. 1990); George L. Lenard, Products Liability of Successor Corporations: A Policy Analysis, 58 Ind. L.J. 677, 705-6.

16 Ray v. Alad Corp., 19 Cal. 3d 22 (1977)

17 Id. at $24-8$.

$18 \mathrm{Id}$. at $28-30$

19 Id. at 31 .

Escola v. Coca Cola Bottling Co., 24 Cal. 2d 453, 462

1 Ray v. Alad Corp., 19 Cal. 3d 22, 31 (1977). Ray was followed in Foster v: Mooney Aircraft Corp., 68 Cal. that the defond a be sued in Califoria (the petition for a hearing by the Supreme Court was denied on May 26, 1977). Two years ater the Court of Appeals decided SanTwo years later, the Court of Appeals decided Sanders $v$. CEG Corp., 95 Cal. App. 3d a de facto merger, but the court noted ders involved a de facto merger, but the court noted
that even if that was not the case, the defendant would be liable under the reasoning in Ray, cert. denied in 09-20-79.

2286 N.J. 332 (1981)

Describing these facts we considered also what was recited in Fish v. Amsted Indus., Inc., 126 Wis. 2d 293 (1985), and Nguyen v. Johnson Machine \& Press Corp., 104 Ill. App. 3d 1141 (1982), two cases involving the same companies.

24 Id. at $341-2$.

290 Pa. Super. Ct. 15 (1981). The Third Circuit assumed in Conway v. White Trucks, Div. of White Motor Corp., 885 F.2d 90, 93 (1989), that the Pennsylvania Supreme Court would follow the product approach. See also, Tracey by Tracey 0 . Whehester Repeating Arms Co., 745 F. Supp. 1099, 1103-5 (E.D.Pa. 1990)

27 ld.

28412 Pa. Super. Ct. 320,328 (1992). The court in Dawejko said that "it will always be useful to consiCorp. 26 1981). The expression "it will be always useful" cannot be read as imposing the presence of the three requirements, neither can it be read as leaving for another moment the decision about the leaving for the three requirements to apply Ray. "To be useful" means that one could consider the presence of the three requirements to decide whether to apply Ray. Thus, at least the way we read Dawejko, the court gave a step back in Hill.

102 Wash. 2d 581 (1984). 97 Cal. App. 3d 890 900 (1979).

Id. at 894 .
32 Id. at 901.

U. Amsted Indus., Inc, 86 N.J. 332, 350 (1981); Bussel v. DeWalt Products Corp., 259 N.J.Super 499, 518-9 (1992)("The Ramirez Court held that what is 'most important' is the 'continuity in the manufacturing of the loriginal manufacture's] product line throughout the history of these asset acquisitions"). cert. denied, 133 N.J. 431.

34 Bussel v. DeWalt Products Corp., 259 N.J.Super 499, 508 (1992).

35 Id. at 517-8 ("essentially' does not mean 'identically"').

36 Id. at $518-9$.

37 Id. at 520

386 N.J. 361 (1981).

See also, Bussel v. DeWalt Products Corp., 259 N.J.Super 499, 518 (1952).

406 Cal. 4th 767 .

42 Stewart v. Telex Communications, Inc., 1 Cal. App. 4th 190 (1991)(a case where the issue is analyzed with some detaill.

43103 Wash. 2d 258 (1984).

103. Was. 2d 258, 265-7 (1984).

Id. at. 267. In In re Related Asbestos Cases, 578 F. Supp. 91, 92-3 (N.D.Cal. 1983), a case involving the same companies, the District Court had already concluded that the destruction of plaintiffs remedy must be caused by the transaction. See also, applying Pennsylvania law, LaFountain u. Webb Indus. Corp., 951 F.2d 544, 548 (3rd Cir. 1991)(the availability of a remedy against the original manufacturer makes the product line exception inapplicable); Tracey by Tracey $v$. Winchester Repeating Arms Co., 745 F. Supp. 1099, 1105 (E.D.Pa. 1990)(Ray requires that the transfer of assets have caused the destruc tion of plaintiff's remedyl; Diaz $v$. South Bend Lathe, Inc., 707 F. Supp. 97, 103 (E.D.N.Y. 1989)(in order to apply Ray, plaintiff should be left without remedy against the original manufacturer).

46 Ray v. Alad Corp., 19 Cal. 3d 22, 25 (1977). 767, 777-9 (1993).

48 Rawlings v. D.M. Oliver, Inc., 97 Cal. App. 3d 890, Rawlings $v$. D.M. Oliver, Inc., 97 Cal. App. $3 d 890$, on that the product had not been mass-produced was not proven in the case

49253 N.J.Super 327 (1991).

5011 U.S.C. sec. 701 et seq.

51 This argument was used in Tracey by Tracey $v$. Winchester Repeating Arms Co., 745 F. Supp. 1099, $1106-$ 8 (E.D.Pa. 1990)(citing Nelson v. Johns-Manville, 745 F.2d 1217 (9th Cir. 1984). See also, Stewart v. Telex Communications, Inc., 1 Cal. App. 4th 190 (1991) (refusing to recognize liability when the purchase of the assets was made in a bankruptcy proceeding unless it was demonstrated that the bankruptcy had been used as a subterfuge to avoid the holding in
Ray).
52 Express Assumption of liabilities, for example.

645 F.2d 620, 625 (1981).

Ray v. Alad Corp., 19 Cal. 3d 22, 31 (1977). Ravings v. D.M. Oliver, Inc., 97 Cal. App. 3d 890 , Id. at 894 .

57 Id. at 901 . But see, supra, note 33

58 Bussel v. DeWalt Products Corp., 259 N.J.Super 499 $518-9$ (1992)

59 Id. at $517-8$

See, Beatrice Co. V. Bd. of Equalization, 6 Cal. 4th 767 (1993); Hall v. Armstrong Cork, 103 Wahs. 2d 258 (1984). But see what we wrote about Bussel v. DeWalt Products Corp., 259 N.J.Super 499, (1992), supra, p. 14.

ves v. Bruno Sherman Corp., 86 N.J. 361 ve Walt Products Corp.. 259

Co. U. Alad Corp., 19 Cal. 3d 22, 25 (1977); Beatrice 列 9 (1993).

896-8 (1979). (1991).

Turner V. Bituminous Casualty Co., 397 Mich. 406 420 (1976); Nguyen v. Johnson Machine \& Press Corp., fic Corpp. 3d 1141, 1143 (1982); Louisiana-PactIc Corp. v. Asarco, Inc., 909 F.2d 1260, 1264 (9th Cir. 1990): Richols v. Roper-Whitney Co., 843 F. Supp. 799, 803-4 (D.N.H. 1994); Tracey by Tracey v. Winchester Repeating Arms Co., 745 F. Supp. 1099, 109 (E.D.Pa. 1990); Diaz v. South Bend La
F. Supp. 97, 100 (E.D.N.Y. 1989).

66 Nichols v. Roper-Whitney Co., 843 F. Supp. 799, 804 (D.N.H. 1994).

Diaz v. South Bend Lathe, Inc., 707 F. Supp. 97, 100 1 (E.D.N.Y. 1989)(citing two more cases).

Nguyen v. Johnson Machine \& Press Corp., 104 Ill. App. 3d 1141, 1143-4 (1982); Louisiana-Pacific Corp. Travis v. Harris Carp. 565 F.2d 443, 447 (7th Cir. Travis v. Harris Corp., 565 F.2d 443, 447 (7th Cir.
1977).

69 Nissen Corp. v. Miller, 323 Md. 613, 620 (1991); Dawejko v. Jorgensen Steel Co., 290 Pa. Superior Ct. ting Arms Co., 745 F. Supp. 1099, 1110 (E.D.Pa. 1990).

70 The expression was used in the dissenting opinion in Turner v. Bituminous Casualty Co., 397 Mich. 406, 448 (1976).

71 In a de facto merger case we have different companies, one buys the assets of the other, and the shareholders of the seller become shareholders of the buyer corporation. In a mere continuation, both companies were originally owned by the same people. The dissolution of the seller corporation is not a requirement to apply the mere continuation exception. 
72501 F.2d 1145 (1st Cir. 1974)

3 Bernard v. Kee Mfg. Co., 409 So. 2d 1047, 1049 (Fla. 1982): Ramirez v. Amsted Indus., Inc., 86 N.J. 332, $343(1981)$.

74 LaFountain v. Webb Indus. Corp., 951 F.2d 544, 547 (3rd Cir. 1991). Despite the observation made in Ray v. Alad Corp., 19 Cal. 3d 22, 30 (1977).

75397 Mich. 406(1976).

76 The product line approach was later rejected by the Supreme Court of New Hampshire in Simoneau

South Bend Lathe, Inc., 130 N.H. 466 (1988).

77 Cyr v. B. Offen \& Co., Inc., 501 F.2d 1145, 1153-4 (1st Cir. 1974).

78397 Mich. 406

79 Id. at $417-8$.

80 id. at $421-3$.

81 Id.

84 Turner V. Bituminous Casualty Co 397 Mich. 406 120 (1976) See also, about the fors a de facto merger case Nguen $v$. Johnson Machined in Press Corp 104 III. App 3d 1141, $1143(1982)$ : Loisiana-Pacific Corp. v. Asarco, Inc., 909 F.2d 1260 . 1264 (9th Cir 1990): Nichols u. Roper-Whit 1260. 843 F. Supp 799, 803-4 (D.N.H. 1994): Tracey by Tracey v. Winchester Repeating Arms Co., $745 \mathrm{~F}$. Supp. 1099, 1109 (E.D.Pa. 1990); Diaz v. South Bend Lathe, Inc., 707 F. Sựp. 97, 100 (E.D.N.Y. 1989).

8588 Mich. App. 747 (1979). See also, City Environmental, Inc. v. Chemical Co., 814 F. Supp. 624, 635 (E.D. Mich. 1993).

86 Lenire v. Garrard Drugs, 95 Mich. App. 520.

87 Id. at 525.

88124 Mich. App. 641 .

89434 So. $2 \mathrm{~d} 766$

90 Id. at $771-2$.

91 Id. at 772 .

862 F. Supp. 175, 178 (E.D.Mich. 1994)

See, or example, Nissen Corp. v. Miller, 323 Md. 613 632 (1991)( Like the majorily of our sister states, cessor corporations with its four tradition of suc-

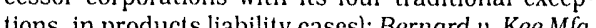
Co. 409 So $2 \mathrm{~d} 1047,1049$ (1982) (Few juristictions have begun to extend products liablity): Reed Armstrong Cork Co. $577 \mathrm{~F}$ Supp. 246, 248 (E. D.Ark. 1983) (assuming that Arkans. 246,248 (E.D.Ark. jority of the courts in retaining the traditional ap-

proach).
Leannais $v$ Cincinnati, $565 \mathrm{~F} .2 \mathrm{~d} 437$. The Wis-

consin law will be analyzed further in this The Wis-

5 Id. at 441 . See also, Travis v. Harris Corp., 565 F. $2 d$ 443 (7th Cir. 1977).

6 See, Justice Bablitch dissenting opinion in Fish v. Amsted Indus., Inc., 126 Wis. 2d 293, 322 (1985).

97409 So. 2d 1047 (1982)

98 Id. at $1049-50$.

99 ld. at 1050.
100 Id.

101534 So. 2d 1253 (1988).

. 6. 427-8 (1976).

This argument was used by Justice Callow in his 108 Wis. 2d 72, 97 (1982).

104 Ramirez v. Amsted Indus., Inc., 86 N.J. 332, 354 (1981).

106104 Ill. App. 3d 1141 (1982). Nguyen was followed in Myers v. Putzmeister, Inc., 232 Ill. App. 3d 419,

107 Describing these facts we considered also what was recited in Fish v. Amsted Indus., Inc., 126 Wis. 2d 293 (1985), and Ramirez v. Amsted Industries, Inc. (1) N.J. 332 (1981), two cases involving the same

08 . 104 IIt. App.

104. App. 3d 1141, 1146-7 (1982).

W. H. Auden, Law Like Love.

The

104 II.

114108 Wis. $2 \mathrm{~d} 72$.

115 Id. at 77.

116 Id. at $78-9$

17 Id. at 80.

18 See George L. Lenard, Products Liability of Successor Corporations: A Policy Analysis, 58 Ind. L.J. 677 703 (1983)(Tift imposed liability "under a greatly expanded mere continuation exception"). But see, Richard A. Epsten, Cases and Matenals on Torts 661 (Little, Brown and Co., 5th ed. 1990)(Tift applied the mere continuation exception.

119 Actually, one could argue that even if the cour was only stressing that the sole proprietorship could not avoid liability by creating a corporation to run his business the court was in fact exten ding the mere continuation exception

120108 Wis. $2 \mathrm{~d} 105$

121 126 Wis. $2 \mathrm{~d} 293$.

123 Id. at $301-2$

123 Id. at $301-2$.

125 Schumacher v. Shear Co., 59 N.Y. 2d. 239 (1983).

2643 N.Y. 2d 823 (1977).

27 See also Bardere u. Zafir 63 N.Y $2 d 850$ (1984) affirmed a decision to dismiss the complaint for failure to state a cause of action because there was missing allegation of any one of the four circumstances that traditionally support a claim of successor liability).

28 But one could ask if Ray could not really be applied given the facts in Schumacher. Here, the successor had acquired all the assets, including the exclusive right to manufacture and sell the predecessor's products, the inventory and the tra- de name. Moreover, the predecessor had discontinued its business, and at the time of the judgment had no liability insurance, employees or business volume, but only a few assets. Moreover, not all the factors described in Turner should be present to apply the continuity of enterprise exception. Haney u. Bendix Corp., 88 Mich. App. 747 (1979); City Environmental, Inc. v. Chemical Co., $814 \mathrm{~F}$. Supp. 624, 635 (E.D.Mich. 1993)

129144 Vt. 305

130323 Md. 613 (1991)

$131 \mathrm{Id}$, at 624 .

32791 F. Supp. 871 (D.D.C. 1992)

33 Turner v. Bituminous Casualty Co., 397 Mich. 406 428 (1976)

134 Cyr v. B. Olfen \& Co., Inc., 501 F.2d 1145, 1154

135 The argument was used by Justice Callow in his dissenting opinion in Tift v. Forage King Indus., Inc. 108 Wis. $2 d$ 72 86 (1982)

136 Id. at 99.
137 Tift v. Forage King Indus., Inc., 108 Wis. 2d 72, 97. (1982).

138 Ray v. Alad Corp., 19 Cal. 3d 22, 31 (1977).

139 See supra, pp. 11-14.

40 Otherwise we would apply one of the traditional exceptions to the rule of no successor hability.

141 Suter v. San Angelo Foundry and Machine Co., 81 N.J. 150, 173-74 (1979).

142 This is not a new idea. See, Phillips, supra, note 2, at 929 (successor product liability should turn on the issue of whether an ongoing business has been purchased).

143 Nieves v. Bruno Sherman Corp., 86 N.J. 361, 369

44 See, Nissen Corp. v. Miller, 323 Md. 613, 620 (1991)(this distinction is made between the mere terprise exception).

145 Turner V. Bituminous Casualty Co., 397 Mich. 406 ,

146290 Pa. Super. Ct. 15 (1981). 